\title{
Efek Kopling pada Filter Metamaterial Coplanar Waveguide Menggunakan SRRs Persegi Panjang Horizontal
}

\section{Coupling Effect in Metamaterial Coplanar Waveguide Filter Using Horizontal Rectangular SRRs}

\author{
A. A. Fathnan", Taufiqqurrachman, Y. N. Wijayanto, D. Mahmudin, P. Daud \\ Pusat Penelitian Elektronika dan Telekomunikasi, Lembaga Ilmu Pengetahuan Indonesia \\ Komp LIPI Gd 20, Jl Sangkuriang 21/54D, Bandung 40135, Indonesia
}

\begin{abstract}
Abstrak
Dalam penelitian ini telah dilakukan pembuatan filter gelombang mikro menggunakan teknologi coplanar waveguide (CPW) yang dibebani dengan struktur metamaterial. Struktur metamaterial tersebut terdiri dari sepasang resonator cincin terbelah (split ring resonators/SRRs) berbentuk persegi panjang yang dicetak di belakang substrat dielektrik. Sementara itu, CPW dicetak dengan tambahan konektor kecil tepat di atas SRRs tersebut. Variasi panjang dan lebar dari SRRs persegi panjang (horizontal dan vertikal) telah dilakukan untuk melihat efek dari kopling antara saluran transmisi CPW ke SRRs. Variasi jarak antara sel-sel resonator (SRRs) juga telah disimulasikan untuk melihat efek dari kopling antara sel-sel yang berdekatan. Analisis dengan simulasi elektromagnetik dan data dari eksperimen telah menunjukkan bahwa kinerja bandwidth filter yang berbeda telah ditemukan dengan merubah struktur SRRs maupun dengan merubah jarak antara sel-sel resonator (SRRs). Telah ditemukan pula bahwa kontribusi yang signifikan dari kopling antara CPW ke SRRs menunjukkan bahwa SRRs persegi panjang horizontal dapat dimanfaatkan untuk meningkatkan performa filter. Hasil penelitian ini dapat digunakan untuk menganalisis konfigurasi geometris SRRs yang memberikan optimalisasi praktis paling baik untuk pembuatan filter metamaterial CPW.
\end{abstract}

Kata kunci: filter metamaterial, resonator cincin terbelah (SRRs) persegi panjang, coplanar waveguide, efek kopling.

\section{Abstract}

In this study, a microwave filters using coplanar waveguide technology loaded with metamaterial structure has been fabricated. The metamaterial structure consists of pairs of split ring resonator (SRRs) in rectangular shape printed on the back of the dielectric substrate. Meanwhile, CPW is printed with an additional small connector just above the SRRs. Variation to the length and width of the rectangular SRRs (horizontal and vertical) have been conducted to see the effect of coupling between CPW transmission line to SRRs. Distance variation between cells of resonators (SRRs) has also been simulated to see the effects of coupling between adjacent cells. Electromagnetic simulation and data from the experiments show that different bandwidth performance isfound by changing the structure of SRRs as well as by changing the distance between the cells of resonators (SRRS). It is also obvious that significant contribution of CPW to SRRs coupling indicate that SRRs with horizontal rectangular shape can be used to improve the performance of the filter. The results can be used to analyze the geometric configuration of SRRs which provide best practical optimization for the fabrication of metamaterial CPW filter.

Keywords: metamaterial filter, rectangular split ring resonator, coplanar waveguide, coupling effect.

\section{Pendahuluan}

Untuk meningkatkan kualitas dan kuantitas produk elektronika dan telekomunikasi dalam negeri, serta menekan jumlah impor bahan baku elektronika dan telematika, pemerintah perlu terus meningkatkan daya saing industri manufaktur dengan mensinergikannya pada hasil penelitian yang mutakhir dan bermanfaat. Salah satu penelitian mutakhir di bidang elektronika dan telekomunikasi adalah metamaterial.

Baru-baru ini, jenis jalur transmisi dengan resonansi berdasarkan metamaterial telah menarik perhatian yang cukup tinggi di lingkup penelitian komponen gelombang mikro maupun optik. Konsep dasar di balik pembuatan komponen tersebut adalah

\footnotetext{
* Corresponding Author.

Email: ashif.aminulloh.fathnan@lipi.go.id

Received: February 23, 2015; Revised: March 19, 2015

Accepted: March 28, 2015

Published: June 30,2015

(c) 2015 PPET - LIPI

doi : $10.14203 /$ jet.v15.18-22
}

dengan menyediakan permitivitas negatif dan permeabilitas negatif dalam media jalur transmisi yang menghasilkan indeks bias negatif. Perangkat ini biasanya dibuat menggunakan pabrikasi jalur transmisi dengan pembebanan oleh resonator yang dapat berupa split-ring resonators (SRRs) atau coupled split ring resonators (CSRRs). Saluran transmisi itu sendiri dapat dibuat dalam struktur microstrip [1] ataupun coplanar waveguide [2].

Dalam jenis struktur coplanar waveguide, SRRs yang dicetak di bagian belakang substrat dielektrik, memberikan permeabilitas efektif negatif dalam bandwidth kecil di atas frekuensi resonansi. Sementara di sisi lain dari substrat, coplanar waveguide dengan konektor ukuran kecil diposisikan tepat di atas SRRs, bertindak sebagai plasma magnetik yang menyediakan permitivitas negatif. Ketika frekuensi plasma direkayasa sedemikian rupa sehingga berada di atas frekuensi resonansi dari SRRs, efek yang dihasilkan adalah permitivitas dan permeabilitas negatif atau propagasi gelombang tangan kiri. 
Aplikasi berbagai perangkat berdasarkan konsep saluran transmisi dengan permitivitas dan permeabilitas negatif atau gelombang tangan kiri ini telah merambah ke berbagai perangkat, termasuk di antaranya komponen penunda fase, pembagi, dan komponen penyaring/filter [3]-[5], menunjukkan penting dan urgensinya penelitian ini. Beberapa penelitian pada karakterisasi jalur transmisi dengan SRRs juga telah dilaporkan di banyak publikasi, salah satunya adalah analisis numerik interaksi antara dua atau lebih SRRs [6] yang menyimpulkan bahwa interaksi bersifat kopling magnetik ataupun elektrik dengan kompleksitas yang cukup tinggi dan sangat bergantung pada pengaturan geometris SRRs.

Analisis struktur dengan sirkuit ekuivalen juga telah dilakukan baru-baru ini, dengan motivasi utama agar desain dapat dilakukan dengan lebih mudah. Karakteristik propagasi coplanar waveguide dengan SRRs telah dianalisis menggunakan konsep dinding magnetik (magnetic wall) [7]. Model rangkaian sirkuit ekuivalen dengan peningkatan performa juga telah diusulkan dengan mempertimbangkan berbagai elemen struktur, termasuk SRRs, elemen induktif dan jalur transmisi CPW [8]. Kopling antara SRRs yang membentuk pasangan dalam satu sel juga telah dipelajari [9]. Pembahasan efek kopling antara resonator yang berdekatan juga telah dilakukan, yang menyimpulkan bahwa bandwidth stop-band (untuk kasus bandstop filter) dapat ditingkatkan dengan membuat jarak antara SRRs semakin dekat [10].

Dalam tulisan ini, efek kopling antara jalur transmisi CPW ke SRRs serta sel SRRs yang berdekatan dipelajari lebih lanjut. Analisis numerik menggunakan simulasi elektromagnetik gelombang penuh dilakukan dengan tujuan untuk memahami efek kopling. Hasil pengukuran menggunakan instrumen analisis jaringan vektor juga digunakan sebagai justifikasi dari hasil simulasi. Sel metamaterial terdiri dari sepasang SRRs dengan jarak yang relatif kecil, sehingga efek kopling tidak dapat diabaikan. Pada penelitian ini, digunakan SRRs persegi panjang sehingga efek kopling akan meningkat. Variasi panjang persegi panjang (horizontal dan vertikal) dari SRRs serta jarak antara sel yang berdekatan telah dilakukan untuk melihat efek dari kopling terhadap performa filter. Struktur perangkat filter dibahas secara rinci dalam bagian II, efek kopling dibahas dalam bagian III, pembahasan kemudian disimpulkan dalam bagian Kesimpulan.

\section{STRUKTUR Filter}

Struktur filter metamaterial coplanar waveguide menggunakan SRRs persegi panjang ditunjukkan pada Gambar 1. Struktur sel metamaterial terdiri dari sepasang SRRs persegi panjang dengan konektor shunt ditempatkan tepat di atas slot coplanar waveguide. Dimensi coplanar waveguide telah diatur sehingga memenuhi karakteristik impedansi $50 \Omega(\mathrm{W}=24,6 \mathrm{~mm}$, $\mathrm{G}=0,6 \mathrm{~mm})$, dengan menggunakan persamaan sebagai berikut [11];

$$
Z_{0}=\frac{1}{c C_{\text {air }} \sqrt{\varepsilon_{\text {eff }}}}=\frac{30 \pi}{\sqrt{\varepsilon_{\text {eff }}}} \frac{K\left(k_{0}^{\prime}\right)}{K\left(k_{0}\right)}
$$

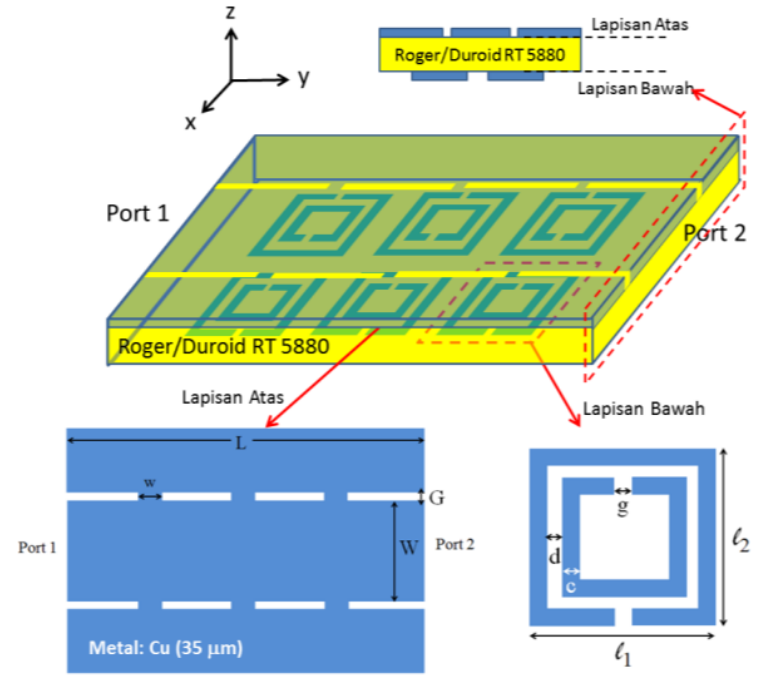

Gambar 1. Ilustrasi Struktur Filter Metamaterial dengan SRRs pada CPW dengan Inset Menunjukkan Parameter Geometris dari SRRs Persegi

di mana,

$$
\begin{gathered}
\varepsilon_{\text {eff }}=\frac{C_{\mathrm{CPW}}}{C_{\mathrm{air}}}=1+\frac{\left(\varepsilon_{\mathrm{r} 1}-1\right)}{2} \frac{K\left(k_{1}\right)}{K\left(k_{1}^{\prime}\right)} \frac{K\left(k_{0}^{\prime}\right)}{K\left(k_{0}\right)} . \\
k_{1}=\frac{\sinh \left(\pi S / 4 h_{1}\right)}{\sinh \left\{[\pi(S+2 W)] / 4 h_{1}\right\}} \\
k_{1}^{\prime}=\sqrt{1-k_{1}^{2}} . \\
k_{0}=\frac{S}{S+2 W}
\end{gathered}
$$

Dari persamaan tersebut impedansi dapat diperoleh dengan menggunakan parameter struktur dari CPW di mana S adalah jarak antara dua slot pada CPW dan W adalah lebar metal tengah di mana port sinyal berada (lihat Gambar 1). Kedua parameter ini kemudian menjadi penentu nilai modulus eliptik $\left(k_{0}\right.$ dan $\left.k_{1}\right)$ seperti tampak pada persamaan (3) dan (4), yang kemudian digunakan untuk menghitung integral eliptis pada persamaan (2) dan (1), sehingga diperoleh nilai impedansi.

Sementara itu konektor tambahan di slot CPW telah diatur dengan ukuran $\mathrm{w}=2,4 \mathrm{~mm}$. Sel SRRs kemudian diparalel tiga kali untuk mendapatkan efek kopling antara sel-sel yang berdekatan. Dimensi dari SRRs juga telah dirancang untuk mendapatkan operasi bandpass di frekuensi $S$-band 2,2 GHz. SRRs persegi panjang memiliki lebar $c=1,2 \mathrm{~mm}$, jarak pemisahan $s=1,2 \mathrm{~mm}$ dan celah $g=1,2 \mathrm{~mm}$. Panjang awal dari SRRs persegi panjang (panjang horizontal $l_{1}$ dan panjang vertikal $l_{2}$ ) adalah $l_{1}=l_{2}=13,2 \mathrm{~mm}$.

Untuk membuat sampel metamaterial filter, teknik mask/foto-etsa standar kemudian diaplikasikan pada substrat dielektrik Roger/Duroid RT $5880\left(\varepsilon_{\mathrm{r}}\right.$ dielektrik konstan $=2,2$; loss tangen $\tan \delta=0,0009$, ketebalan $=$ $1,575 \mathrm{~mm}$ ). Fotografi Hasil dari pabrikasi dapat dilihat pada Gambar 2 di mana 2 (a) menunjukkan hasil pabrikasi tampak belakang dan 2 (b) tampak depan. Sementara itu, analisis numerik dari struktur filter CPW dengan SRRs telah dilakukan menggunakan perangkat lunak komersial Agilent Momentum. 

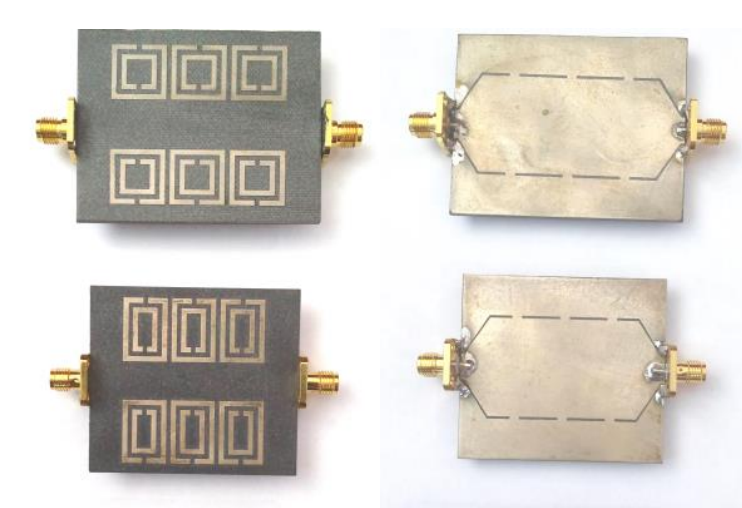

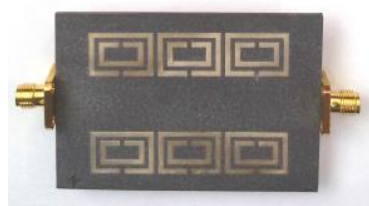

(a)

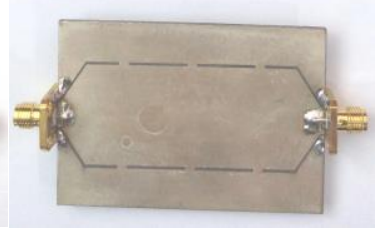

(b)
Gambar 2. Foto Prototipe Hasil Pabrikasi Dengan SRRs Berbentuk Persegi, Persegi Panjang Vertikal dan Horizontal, di mana (a) Tampak Belakang dan (b) Tampak Depan.

Untuk menganalisis pengaruh kopling, beberapa parameter seperti $l_{1}, l_{2}$, dan $s$ dibuat bervariasi. Implikasi praktis seperti Q-faktor dan $f_{0}$ atau frekuensi tengah kemudian dievaluasi untuk melihat lebih jauh efek dari kopling SRRs ke CPW serta performa dari filter tersebut.

\section{EFEK KOPLING}

\section{A. Variasi Jumlah Sel SRRs pada Filter dengan SRRs Persegi}

Untuk melihat pengaruh penggunaan jumlah sel SRRs, dilakukan perbandingan antara hasil simulasi filter menggunakan 1 sel SRR dan 3 sel SRR. Hasil perbandingan ini ditunjukkan pada Gambar 3 (a). Dengan menambahkan 2 sel SRRs, penolakan di luar band yang diinginkan dapat ditingkatkan cukup drastis. Bandpass yang sempit serta penolakan yang tinggi diperoleh dengan membuat tiga SRRs digabungkan secara berjajar (cascade) dan tiga pasang konektor tambahan di atas SRRs pada slot CPW. Dengan demikian, dapat dipahami bahwa penggunaan sel SRRs lebih banyak akan memberikan respon filter yang lebih baik.

Akan tetapi, pada simulasi ini juga dapat diketahui bahwa kerugian penyisipan atau insertion loss terdegradasi dengan nilai tertentu pada filter dengan 3 sel SRRs, meskipun masih pada nilai yang dapat ditolerir. Perilaku ini dapat dijelaskan sebagai efek kopling magnetik antara saluran transmisi ke SRRs serta antara SRRs yang bersebelahan. Sebagaimana dijelaskan oleh Balmaz dan Martin [6], meskipun medan listrik dan medan magnet keduanya memberikan induksi resonansi pada SRRs, induksi magnet memberkan pengaruh jauh lebih kuat, sehingga mampu memberikan kontribusi terhadap adanya resonansi di filter.

Selanjutnya, untuk klarifikasi dari hasil simulasi pada filter dengan 3 sel SRRs berbentuk persegi ini, dilakukan perbandingan antara hasil simulasi dan hasil pengukuran. Grafik dari hasil simulasi serta dari hasil pengukuran dari filter jenis ini ditunjukkan pada Gambar 3 (b). Kemiripan antara simulasi dan pengukuran terlihat dengan cukup jelas, sementara sedikit perbedaan antara keduanya, terutama pada perbedaan kerugian penyisipan atau insertion loss sebesar $\pm 1 \mathrm{~dB}$, dapat dianggap sebagai toleransi pabrikasi. Letak frekuensi tengah antara hasil pengukuran dengan simulasi juga terlihat cukup sesuai yang membuktikan keandalan simulasi yang digunakan.

\section{B. Variasi Panjang Horizontal dan Vertikal dari SRRs}

Efek lain dari kopling dapat dilihat dengan mempelajari ukuran SRRs. Seperti telah diketahui bahwa frekuensi resonansi SRRs adalah bergantung pada rangkaian ekuivalen kapasitor dan induktornya. Untuk itu, variasi panjang persegi panjang SRRs (panjang horizontal $l_{1}$ dan panjang vertikal $l_{2}$ ) tidak akan merubah frekuensi tengah dari filter jika tetap mempertahankan total keliling yang sama. Pada penelitian ini, telah dilakukan variasi ukuran SRRs dengan parameter $l_{1}$ dan $l_{2}$ mengacu pada nilai yang ditunjukkan pada Tabel 1. Perubahan dilakukan pada $l_{1}$ atau $l_{2}$ sementara keliling SRRs dijaga agar tidak berubah, sehingga frekuensi resonansi tidak berubah. Seperti dapat dilihat dari Gambar 4, frekuensi pusat atau $f_{0}$ hampir sama diperoleh dengan tetap menjaga total keliling SRRs sebesar 52,8 mm.

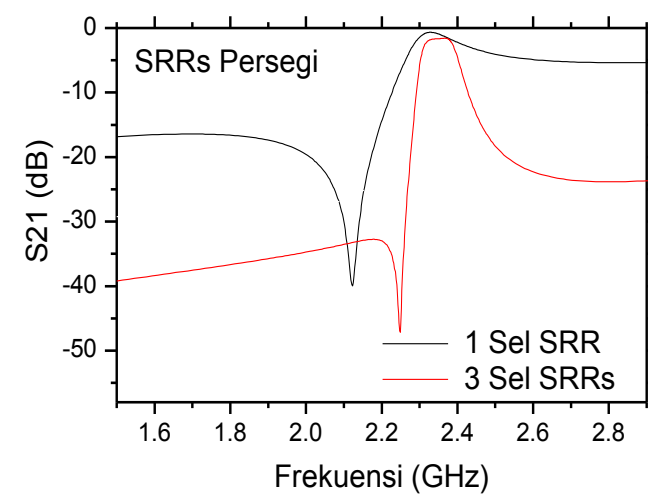

(a)

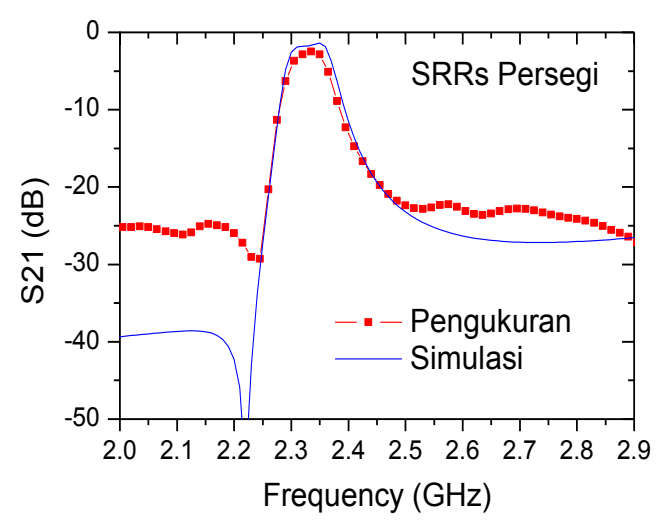

(b)

Gambar 3. (a) Hasil Simulasi S21 Perbandingan 1 Sel dan 3 Sel SRRs Pada Filter Metamaterial CPW, (b) Hasil S21 Dari Simulasi dan Pengukuran Filter Metamaterial CPW Dengan Tiga Sel SRRs. 
TABEL 1

PARAMETER STRUKTUR SRRS

\begin{tabular}{|l|c|c|c|}
\hline & SRRs Persegi & $\begin{array}{c}\text { SRRs Persegi } \\
\text { Panjang Horizontal }\end{array}$ & $\begin{array}{c}\text { SRRs Persegi } \\
\text { Panjang Vertikal }\end{array}$ \\
\hline$l_{1}$ & $13,2 \mathrm{~mm}$ & $15,6 \mathrm{~mm}$ & $10,8 \mathrm{~mm}$ \\
\hline$l_{2}$ & $13,2 \mathrm{~mm}$ & $10,8 \mathrm{~mm}$ & $15,6 \mathrm{~mm}$ \\
\hline & $\mathbf{5}$ & $\square$ & $\mathbf{\square}$ \\
\hline
\end{tabular}

Dengan mengamati kinerja bandwidth pada tiga konfigurasi filter yang berbeda ini, diperoleh bahwa SRRs dengan panjang horizontal $\left(l_{1}\right)$ yang lebih besar memiliki bandwidth yang lebih luas yang menunjukkan penurunan kinerja Q-faktor. Kecenderungan adalah sama untuk kedua konfigurasi filter baik dengan 1 sel SRRs (Gambar 4 (a)) dan maupun 3 sel SRRs (Gambar 4 (b)).

Perilaku ini dapat dipahami sebagai akibat dari adanya kopling antara saluran transmisi CPW ke SRRs yang menjadi lebih besar dengan membuat panjang horizontal SRRs lebih besar. Kopling ini dibentuk oleh medan magnet yang memasuki SRRs sehingga memproduksi arus yang mengalir dalam SRRs tersebut. Untuk memahami lebih lanjut fenomena kopling ini, dibuatlah simulasi kerapatan arus (current density) di permukaan CPW menggunakan simulasi Sonnet.

Seperti dapat dilihat dari Gambar 5 (a) dan 5 (b), di mana ditunjukkan hasil simulasi kerapatan arus di

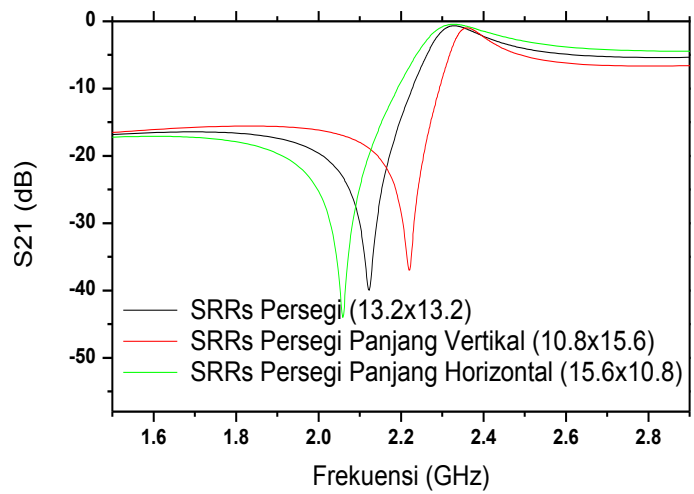

(a)

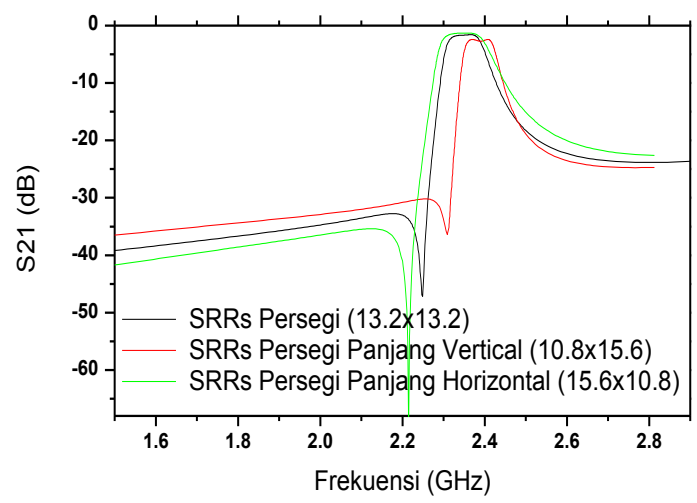

(b)

Gambar 4. (a) Pengaruh Perubahan Panjang Horizontal dan Panjang Vertikal dari Srrs Persegi Panjang Dengan Menjaga Keliling Sebesar 52,8 Mm dalam Satu Konfigurasi Sel, (b) Efek Kopling pada Konfigurasi Tiga Sel.
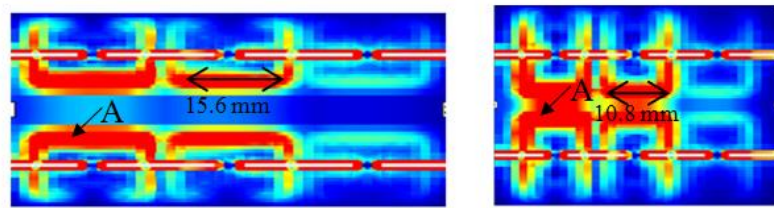

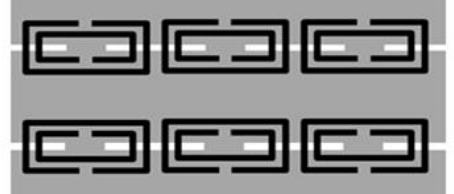

(a)

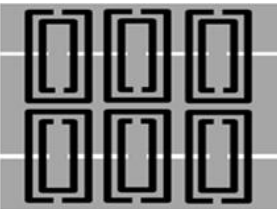

(b)
Gambar 5. Hasil Simulasi Kerapatan Arus pada Frekuensi Resonansi dan Struktur dengan SRRs Persegi Panjang Horizontal (a), dan Persegi Panjang Vertikal (b).

permukaan CPW. Dapat diamati bahwa kerapatan arus di titik A adalah memiliki nilai maksimum, sedangkan saat dekat dari celah SRR kerapatan arus memiliki nilai hampir nol. Dengan konfigurasi SRRs horizontal $15,6 \times 10,8 \mathrm{~mm}$ seperti yang ditunjukkan pada Gambar 5 (a), arus maksimum di titik A mengalir di konduktor yang lebih panjang. Sebaliknya, dengan konfigurasi SRRs vertikal $10,8 \times 15,6 \mathrm{~mm}$ arus di titik A mengalir pada konduktor yang lebih pendek. Hal ini menunjukkan bahwa, dengan melakukan variasi panjang SRR horizontal dan vertikal, kopling magnetik telah berubah dan membuat performa filter (kinerja bandwidth) berubah. Fenomena ini dapat dimanfaatkan dengan mengatur panjang SRR vertikal dan horizontal sedemikian rupa sehingga memenuhi kebutuhan filter (kinerja bandwidth) yang diinginkan.

\section{Variasi Jarak Antar SRRs}

Dalam rangka untuk lebih memahami efek kopling antara SRRs yang berdekatan, analisis karakteristik transmisi dengan melakukan perubahan terhadap jarak pemisahan antara SRRs juga telah dilakukan. Studi yang sama telah dilakukan oleh Balmaz dan Martin [6] di mana serangkaian SRRs persegi panjang telah diamati. Studi lain [10] melakukan penelitian pada SRRs persegi panjang yang diatur sedemikian rupa pada jalur transmisi coplanar waveguide. Kedua studi menunjukkan bahwa kopling akan meningkat seiring dengan jarak antar SRRs yang menurun, di mana dihasilkan bandwidth yang lebih sempit.

Studi yang sama dilakukan pada penelitian ini untuk menunjukkan bagaimana kinerja filter berubah, sebagai akibat dari berubahan jarak (s) antar sel pada filter. Seperti tampak pada Gambar 6 (a), di mana kinerja bandwidth yang tidak sama dapat diamati sebagai akibat dari perubahan nilai $\mathrm{s}$ atau jarak antar SRR. Selain itu dapat diamati pula bahwa perubahan ini diikuti dengan perubahan pada frekuensi tengah $f_{0}$. yang berpengaruh terhadap perubahan nilai Q-faktor seperti terlihat pada Gambar 6 (b). Kecenderungan yang sama dari SRRs vertikal dan horizontal tampak jelas pada Gambar 6 (b) di mana nilai Q-faktor mengecil dengan pertambahan jarak antar sel SRR. Dapat dilihat pula bahwa nilai Q-faktor pada sel SRRs vertikal lebih tinggi dibandingkan SRR horizontal maupun persegi.

Dengan demikian, dapat dipahami bahwa kopling antar sel yang berdekatan meningkatkan performa 


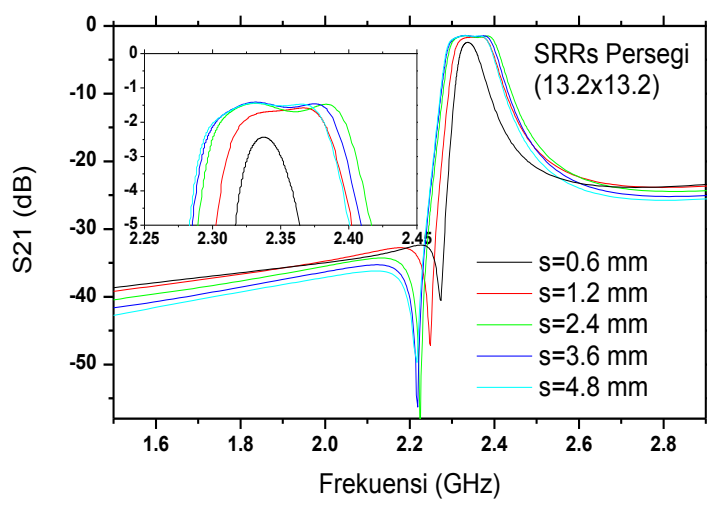

(a)

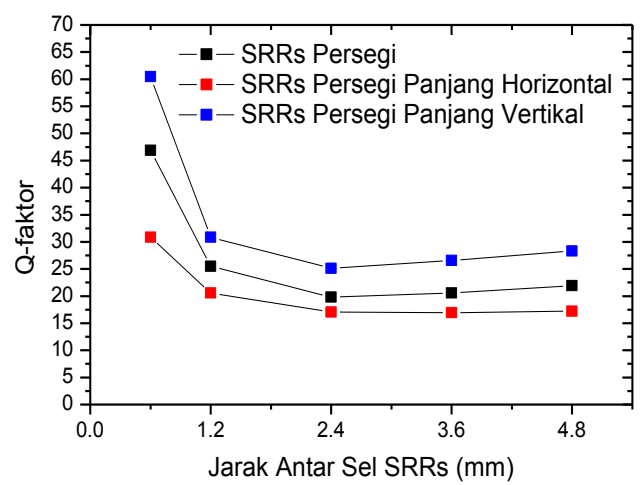

(b)

Gambar 6. (a) Hasil Simulasi S-parameter Filter Sebagai Akibat dari Perubahan Jarak Antar Sel SRRs, (b) Q-faktor dari Filter Sebagai Akibat dari Perubahan Jarak Antar Sel SRRs.

bandwidth pada nilai tertentu, dan akan mencapai titik jenuh saat jarak pemisahan terlalu besar. Oleh karenanya, untuk mendapatkan implementasi praktis yang lebih baik dari filter, pengaturan jarak antar SRRs dapat dibuat sedemikian rupa sehingga nilai Q-faktor sesuai dengan yang diinginkan.

\section{KESIMPULAN}

Pada penelitian ini, telah dilakukan simulasi dan pabrikasi untuk mempelajari efek kopling pada filter metamaterial coplanar waveguide menggunakan SRRs persegi panjang horizontal. Dapat disimpulkan bahwa dengan mengubah panjang horizontal $l_{1}$ dan panjang vertikal $l_{2}$ dari SRRs persegi panjang, kinerja bandwidth dari filter akan turut berubah. Hasil pengukuran dan simulasi $S$-parameter menunjukkan bahwa bandwidth yang lebih luas diperoleh dari SRRs dengan panjang horizontal $\left(l_{1}\right)$ yang lebih besar. Hal ini disebabkan karena peningkatan kopling magnetis antara saluran transmisi CPW ke SRRs.

Pada penelitian ini juga telah dilakukan kajian simulasi terhadap pengaruh perubahan jarak pemisah SRRs terhadap kinerja bandwidth dari filter. Hasil simulasi tersebut menunjukkan bahwa efek kopling akan berkurang karena pemisahan yang lebih besar dan akan mencapai titik jenuh saat jarak pemisahan menjadi terlalu besar. Hasil dan analisis pada penelitian ini dapat digunakan sebagai dasar untuk melakukan optimalisasi kinerja filter metamaterial coplanar waveguide menggunakan SRRs persegi panjang dengan melakukan pengaturan struktur geometri secara tepat.

\section{UCAPAN TERIMA KASIH}

Kegiatan ini dilakukan sebagai bagian dari program penelitian "Pengembangan Konverter dari Gelombang Mikro Nirkabel ke Cahaya Menggunakan Antena dan Modulator Optik untuk Aplikasi Telekomunikasi Dan Pengukuran", serta "Rancang Bangun Beam-Former Berbasis Photonic Microring Resonator untuk Antena Phased Array pada Aplikasi Radar" melalui proram penelitian Kompetitif dan Tematik, Lembaga Ilmu Pengetahuan Indonesia (LIPI).

\section{Daftar Pustaka}

[1] J. Bonache, I. Gil, J. G. García, and F. Martín, "Novel microstrip bandpass filters based on complementary split-ring resonators", IEEE Trans. Microw. Theory Tech., vol. 54, no. 1, pp. 265-271, Jan. 2006

[2] F. Martín, F. Falcone, J. Bonache, R. Marqués, and M. Sorolla, "Split ring resonator-based left-handed coplanar waveguide", Appl. Phys. Lett., vol. 83, p. 4652, 2003.

[3] G. V. Eleftheriades, A. K. Iyer, and P. C. Kremer, "Planar negative refractive index media using periodically $\mathrm{L}-\mathrm{C}$ loaded transmission lines", IEEE Trans. Microw. Theory Tech., vol. 50, no. 12 , pp. 2702-2712, Dec. 2002.

[4] M. A. Antoniades and G. V. Eleftheriades, "A broadband series power divider using zero-degree metamaterial phase shifting lines", IEEE Microw. Wireless Compon. Lett., vol. 15, no. 11, pp. 808-810, Nov. 2005.

[5] A. L. Borja, J. Carbonell, V. E. Boria, J. Cascon, and D. Lippens " $2 \%$ bandwidth c-band filter using cascaded split ring resonators", IEEE Antennas and Wireless Propagation Letters, vol. 9, pp 256-259, March 2010.

[6] P. G. Balmaz and O. J. Martin "Electromagnetic resonances in individual and coupled split-ring resonators", Journal of Appl. Phys., vol. 92, no. 5, p. 2929, Sept. 2002.

[7] J. D. Baena, J. Bonache, F. Martín, R. Marqués, F. Falcone, T. Lopetegi, M.A.G. Laso, J. García, I Gil and M. Sorolla, "Equivalent circuit models for split ring resonators and complementary split rings resonators coupled to planar transmission lines", IEEE Transactions on Microwave Theory and Techniques, vol. 53, pp. 1451-1461, April 2005.

[8] F. Aznar, J. Bonache, and F. Martín "Improved circuit model for left-handed lines loaded with split ring resonators", Appl. Phys. Lett. 92, 043512, 2008

[9] L. Su, J. Naqui, J. M. Contreras, and F. Martín "Modeling metamaterial transmission lines loaded with pairs of coupled split-ring resonators", IEEE Antennas and Wireless Propagation Letters, vol. 14, pp. 68-71, 2015.

[10] J. Naqui, A. F. Prieto, F. Mesa, F. Medina, and F. Martín "Effects of inter-resonator coupling in split ring resonator loaded metamaterial transmission lines," Journal of Appl. Phys., 115, 194903, May 2014.

[11] R. N. Simons, Coplanar Waveguide Circuits, Components and System, New York, NY-USA: John Willey and Sons, 2001, pp. $15-21$. 